Article

\title{
A Worldwide Hotspot Analysis on Food Loss and Waste, Associated Greenhouse Gas Emissions, and Protein Losses
}

\author{
Xuezhen Guo*, Jan Broeze, Jim J. Groot ${ }^{\mathbb{B}}$, Heike Axmann and Martijntje Vollebregt \\ Fresh Food \& Chains Department, Wageningen Food \& Biobased Research, PO Box 17, \\ 6700 AA Wageningen, The Netherlands; jan.broeze@wur.nl (J.B.); jim.groot@wur.nl (J.J.G.); \\ heike.axmann@wur.nl (H.A.); martijntje.vollebregt@wur.nl (M.V.) \\ * Correspondence: Xuezhen.guo@wur.nl
}

Received: 21 August 2020; Accepted: 7 September 2020; Published: 11 September 2020

\begin{abstract}
Reducing food loss and waste (FLW) is prioritized in UN sustainable development goals (SDG) target 12.3 to contribute to "ensure sustainable consumption and production patterns". It is expected to significantly improve global food security and mitigate greenhouse gas (GHG) emissions. Identifying "hotspots" from different perspectives of sustainability helps to prioritize the food items for which interventions can lead to the largest reduction of FLW-related impacts. Existing studies in this field have limitations, such as having incomplete geographical and food commodity coverage, using outdated data, and focusing on the mass of FLW instead of its nutrient values. To provide renewed and more informative insights, we conducted a global hotspot analysis concerning FLW with its associated GHG emissions and protein losses using the most recent data (the new FAO Food Balance Sheets updated in 2020). The findings of this research are that there were $1.9 \mathrm{Gt}$ of FLW, $2.5 \mathrm{Gt}$ of associated GHG emissions, and $0.1 \mathrm{Gt}$ of associated protein losses globally in 2017. The results of the FLW amounts, GHG emissions, and protein losses per chain link are given on the scale of the entire world and continental regions. Next to this, food items with relatively high FLW, GHG emissions, and protein losses are highlighted to provide the implications to policymakers for better decision making. For example, fruits and vegetables contribute the most to global FLW volumes, but the product with the highest FLW-associated GHG emissions is bovine meat. For bovine meat, FLW-associated GHG emissions are highest at the consumer stage of North America and Oceania. Oil crops are the major source of protein losses in the global food chain. Another important finding with policy implications is that priorities for FLW reduction vary, dependent on prioritized sustainability criteria (e.g., GHG emissions versus protein losses).
\end{abstract}

Keywords: food loss and waste; GHG emissions; protein losses; global food supply chains; hotspots

\section{Introduction}

According to World Hunger Statistics, about 1 in 9 people globally do not have enough food to lead a healthy active life. The situation can be even worse in the future with the fast-growing world population. The 2050 world population is estimated at 9 billion and it requires a $70 \%$ increase in food production to meet people's demands for food [1]. Despite the precious value of food, it is estimated that a quarter to one-third of food produced for human consumption is lost or wasted. This makes food loss and waste (FLW) a hot research topic, especially during the last five years (e.g., Fiore et al. [2], Fiore et al. [3], Spada et al. [4], Adamashvili et al. [5], Pellegrini et al. [6], Vittuari et al. [7], Vittuari et al. [8], Pagani et al. [9], Ishangulyyev et al. [10]). FLW does not only escalate the issue of food security but also significantly contributes to anthropogenic greenhouse gas 
(GHG) emissions; many, including Springmann et al. [11], estimated that "halving food loss and waste would reduce environmental pressures by $6-16 \%$ compared with the baseline projection". Based on expected production volumes and global dietary changes, Hiç et al. [12] estimated that in 2050 the global FLW-associated GHG emissions in the production phase only will equal the total GHG emissions of the US in 2011. Therefore, FLW is also a serious problem related to climate change.

Given the importance of the topic, efforts have been made for quantifying FLW and associated GHG emissions to provide data-based decision support. However, much of the existing literature just focuses on a limited set of chain stages and specific countries with limited detailing of food commodities [13]. For example, the studies by Quested et al. [14], Wenlock and Buss [15], and Wenlock et al. [16] limited the scope to the household level. Buzby and Hyman [17] and Kantor et al. [18] studied FLW in the US downstream supply chain stages.

Xue et al. [19] conducted a literature review on FLW-related studies. They find that existing studies' spatial coverage is quite limited, with a strong focus on the developed world (e.g., Kling [20], Harrington et al. [21], Engström and Carlsson-Kanyama [22], Williams et al. [23], Leal Filho and Kovaleva [24]). Moreover, existing studies emphasize the retail and consumer stages but overlook the upstream food supply chain (e.g., Hodges et al. [25], Fehr and Romão [26], Jones [27], Loke and Leung [28], Stenmarck et al. [29]). Those studies generate useful information on FLW in the specific country and food commodity combinations but fail to show a bigger picture on the super-nation scales with a holistic commodity and chain coverage. Other relevant studies to address the FLW quantification issues in a partial way include Åhnberg and Strid [30], Beretta et al. [31], Caldeira et al. [32], and Lanfranchi et al. [33], etc.

In addition to the aforementioned country and chain stage-specific studies, limited research has been conducted at continental and global levels with a comprehensive geographical and commodity coverage (hereafter called comprehensive studies). Figure 1 lists the relevant comprehensive studies (including this paper) in chronological order.

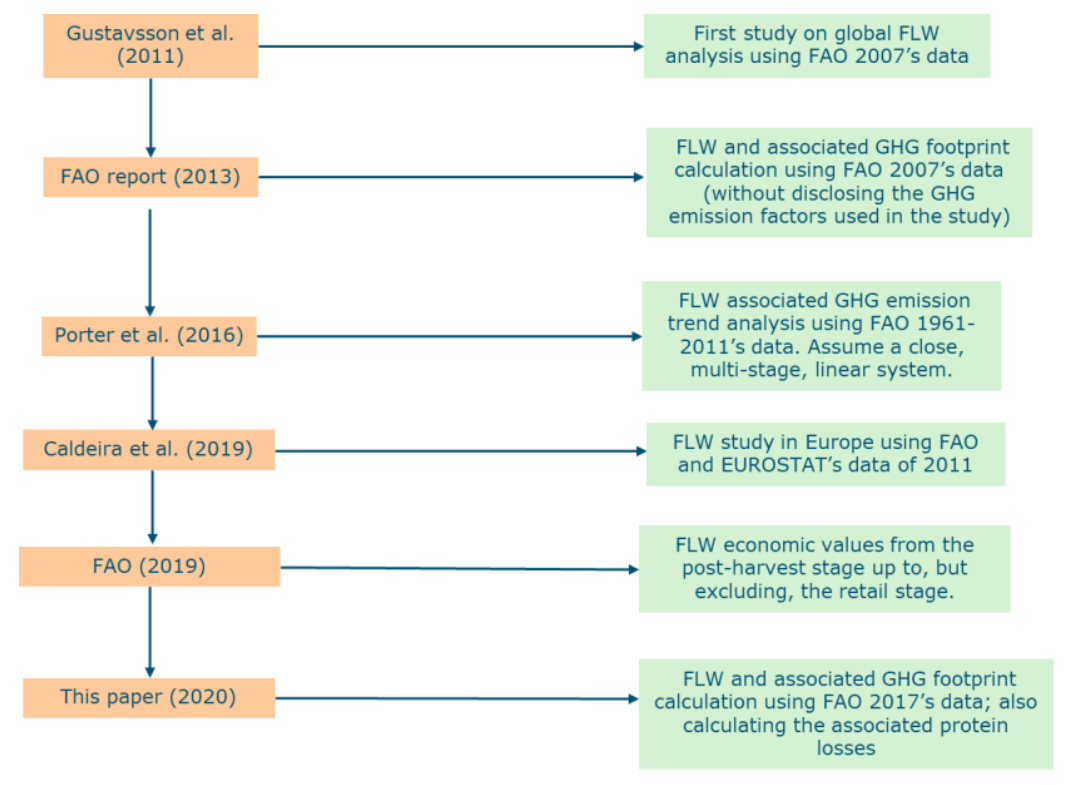

Figure 1. Comparing the relevant comprehensive studies on food loss and waste (FLW) and associated greenhouse gas (GHG) emissions.

Gustavsson et al. [34] is recognized as the first integrated study on global FLW. They specified FLW percentages to individual stages of the food chain based on FAO Food Balance Sheets (FBS) data from 2007. The FLW percentages used in that study were partly derived from the literature; when literature data were not available, the authors used assumptions and estimations to fill the gap. As a follow-up, two years later, FAO issued a technical report that investigated a food wastage footprint 
on natural resources [35]. It used the FAO FBS's data of 2007 with the same FLW percentages in Gustavsson et al. [34] as the basis to calculate GHG emissions associated with FLW. However, this study does not disclose the used emission factors to the readers. Following the two FAO studies, Porter, Reay, Higgins and Bomberg [13] made important contributions to this research line by conducting a more comprehensive literature review on FLW percentages and primary-production-phase GHG emission factors along all supply chain stages, across different supranational regions. They used the FAO FBS's data from 1961 to 2011 to investigate the trend development of FLW and associated GHG emissions. A big advantage of Porter's study is that the used FLW percentages and emission factors were derived from more recent literature; these are transparently listed in the article. Despite its significant scientific contribution, there is one point to be improved for Porter's study. Porter, Reay, Higgins and Bomberg [13] assumed a closed, multi-stage, linear system (i.e., a linear chain) in which the input food mass to each chain stage equals the output food mass (after losses) of its previous stage. This implies that all the raw products need to go through the five supply chain stages including processing. However, many raw products can skip the processing stage and directly go to the food distribution stage as fresh produce. Another limitation of Porter's work is that it only presents the GHG emissions from all FLW but not the chain-wise overview.

After Porter's work, Caldeira, De Laurentiis, Corrado, van Holsteijn and Sala [32] performed a mass flow analysis to quantify FLW in the European Union (EU) and concluded that the stage contributing the most to FLW varies amongst product groups (e.g., for many food groups, the highest share of food waste is at consumption stage, but this is not the case for fish or oil crops). Also in 2019, FAO issued another report to introduce their Global Food Loss Index [36,37]. Instead of looking into the FLW mass, it calculated the economic value of FLW. The limitation of this research is that it was based on the survey data from only 23 countries for 10 key commodities and all other data were estimated. Moreover, this analysis only includes part of the food chain (from the post-harvest stage up to, but excluding, the retail stage).

Through the literature review, we observed that existing studies have limitations of lacking comprehensive coverage (e.g., geography, chain stages, food commodities), and using outdated data (e.g., the food volume data before 2011) and literature. Moreover, the existing comprehensive studies hardly addressed the protein loss issue associated with the FLW (except for Alexander et al. [38]), which is very relevant to global food security.

To fill the knowledge gap, we carried out a comprehensive global hotspot analysis on FLW, as well as the associated GHG emissions and protein losses. We used the most up-to-date data (i.e., the new Food Balance Sheets published in 2020) and literature as the basis to provide the policymakers with an updated overview. This study enriches the research line of the comprehensive FLW studies, as shown in Figure 1, along the entire food chain at both regional and global levels.

\section{Materials and Methods}

Similar to the majority of the relevant studies in this field, the primary source to obtain data in this research was the FAO FBS. However, all the previous studies used the old version of FBS with the most recent data year 2011. This research is the first to use the new FBS (updated in 2020) that covers 2017's data. Different from Porter's study, which only considered the primary-production-phase GHG emissions, we also incorporated the emissions due to international transportation in global food trades. The Detailed Trade Matrix (DTM) from FAODATA was used to map the global food trade flows. Because other post-harvest operations (like processing, packaging, refrigerated storage, etc.) largely differ between and even within product categories, we did not include those effects. However, such emissions may be significant (see e.g., Scherhaufer et al. [39]).

A schematic structure of the methodology employed in this research is presented in Figure 2. 


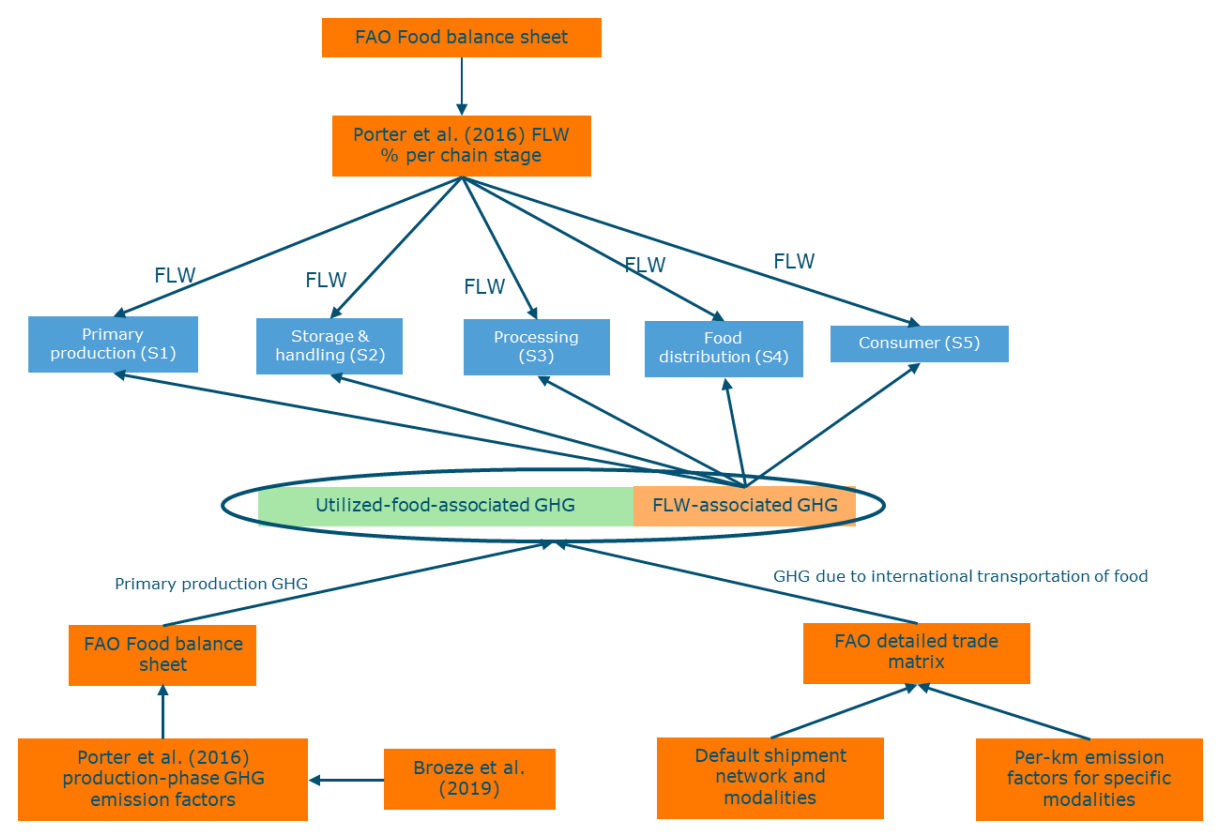

Figure 2. The schematic structure of the methodology applied in this paper.

From the FAO FBS, the most important categories of data include primary production, import and export quantities, processing, food, and feed. The data were retrieved for each country and commodity combination for 2017. Porter, Reay, Higgins and Bomberg [13] is the source from which we derived the FLW percentages. The primary-production-phase GHG emission factors that were applied to the corresponding food chain stages were also obtained from Porter, Reay, Higgins and Bomberg [13]. GHG emissions are expressed as $\mathrm{CO}_{2}$ equivalents. The transportation-related GHG emission factors were from CO2emissiefactoren.nl. The DTM was used to derive import profile (percentages) for each food commodity and each reporter country (i.e., mapping the sourcing flows in percentages from all trade partner countries). The reason why we did not directly use the import quantity numbers registered in the DTM is that those numbers differ from the ones registered in FAO FBS. Since FBS is the leading data source in our study, we decided to use the DTM in an indirect way (i.e., generating the import profile) to keep the data consistent with the FBS data.

The analysis starts with the agricultural production data which we derived from the FBS. Since the production volumes registered in FBS also include the produce for feed, seeds, and other uses, we need to subtract them from the total primary production. To realize that, we applied the same multiplier as defined in Porter's work (see Equation (1)).

$$
\text { FOF }=1-\left(\frac{\text { Feed }+ \text { Seed }+ \text { OtherUses }}{\text { Domestic Supply }}\right)
$$

where FOF indicates the fraction of total primary production that is for food use.

Our analysis is targeted at a food supply chain with 5 stages: primary production (S1), storage and handling (S2), processing (S3), food distribution (S4), and consumer (S5). Here, two features of the FBS are essential: (1) there are no data records available for S2 and S5 and (2) the quantity registered for S1, S3, and S4 is the "net quantity" after subtracting the losses in the referred stage. These features determine that different formulas need to be applied to calculate the FLW for the two types of stages. For S2 and S5, their input food mass is just equal to the registered quantity in S1 and S4 because this registered quantity is the "net quantity" after losses. Multiplying the input food mass of S2 and S5 by the associated FLW percentage, we can obtain the FLW in S2 and S5 using Formula (2a):

$$
\mathrm{FLW}=\mathrm{FM} \times \mathrm{FLWP}
$$


where FLWP is the FLW percentage and FM is the input food mass of S2 or S5. An FLWP is associated with a specific food item and a specific supply chain stage varied by the different regions.

Differently, the FLW losses for S1, S3, and S4 are calculated by solving Equation (2b), also because the registered quantity for those stages is the "net quantity" after losses:

$$
F L W P=\frac{F L W}{N F M+F L W}
$$

where NFM denotes the net food mass after subtracting FLW of the current stage (S1, S3, S4).

Regarding the GHG, only the emissions related to primary production and trade transportation were taken into account due to limited data availability. For the total primary-production-phase GHG emissions, we multiplied the GHG emission factor with the total food mass of the primary production (see Equation (3)).

$$
\text { PGHG }=\text { PFM } \times \text { GHGFP }
$$

where PGHG is the primary-production-phase GHG emissions and GHGFP denotes the GHG emission factor for primary production. PFM is the total food mass in the primary production stage. Here, it is necessary to note that since GHGFP does not include the emissions in the post-harvest chain stages, PGHG only accounts for GHG emissions due to the on-farm activities.

Except for the GHG emissions from the on-farm activities, the emissions from international trade transportation are also considered. To calculate the transportation-related GHG emissions, Equation (4) is used:

$$
\mathrm{TGHG}=\mathrm{TFM} \times \mathrm{D} \times \mathrm{GHGFT}
$$

where TGHG is the transportation-related GHG emissions, TFM is the transported food mass, D is the transportation distance, and GHGFT is the modality-dependent GHG emission factor for food transportation (per km per ton). The transport distances and modality choices were determined by reasonable assumptions for all trade streams listed in the DTM. For countries located on the same continent (or generally reachable by truck), truck transport was presumed. In case a flow goes from one continent to another, the first part of the transport was assumed by truck from the capital city of the origin country to its closest seaport, then by sea freight shipping to the closest seaport of the capital city of the destination country, followed by truck transport from the port to the destination city. For the sea freight, the following two assumptions were made: ambient bulk transport for robust products (e.g., cereals) and reefer transport for perishable products (e.g., meat, dairy, fruit, and vegetables). In the latter case, additional fuel use for reefer cooling was taken into account, i.e., assuming $20 \%$ more GHG emissions than the ambient sea container.

The total GHG emissions were allocated to different supply chain stages according to the amounts of FLW yielded in those stages. The allocated GHG emissions are therefore called FLW-associated GHG emissions, which are the GHG footprints of FLW. For S1 and S2, the corresponding fraction of the primary-production-phase GHG emissions was allocated based on the quantity of FLW generated at that stage. For the remaining stages, the corresponding fraction of both primary production and transportation-related GHG emissions were allocated in accordance with the quantity of FLW per stage.

To calculate the associated protein losses of the FLW, the "FAO Food Composition Table" was used. In the "FAO Food Composition Table", the protein content per food item is listed. We have already obtained the mass of FLW of the food items in different supply chain stages. Therefore, we multiplied the mass of FLW to the protein content of the corresponding food items to derive the protein losses associated with those FLW. 


\section{Results}

\subsection{Food Loss and Waste and the Associated GHG Emissions}

The general results of this research show that the total global FLW in 2017 was about 1.9 Gt of food, which accounted for $29 \%$ of the total primary food production. The GHG emissions associated with these FLW in 2017 are estimated at 2.5 Gt. Note, however, that since GHG emissions due to other post-harvest operations are left out of these analyses, the actual FLW-associated GHG emissions are expected to be somewhat higher than this value.

The international transport-related GHG emissions were very small and only equaled 3\% of the GHG emissions of the total primary production. This shows that the primary agricultural production plays a much more important role in GHG emissions than international food transportation.

Figure 3 presents the overview of major contributors, the hotspots, to global FLW and associated GHG emissions in 2017. Vegetables and fruits contributed the most to FLW, accounting for almost half of the total FLW. Their contributions to the FLW-associated GHG emissions were relatively small, about $16.8 \%$. Bovine meat was not a hotspot at all with respect to FLW (only for $0.7 \%$ of the total FLW), but it was the largest hotspot for the FLW-associated GHG emissions and contributed as much as vegetables and fruits combined (16.3\%). Dairy accounted for $6.8 \%$ of the total FLW and $10.2 \%$ of the associated GHG emissions. Roots and tubers were a hotspot for FLW (12.1\%) but not for the associated GHG emissions (2.7\%). The FLW-associated GHG emissions for fish and seafood and rice were $11 \%$ and $10 \%$, respectively, of the total. Wheat accounted for $6.6 \%$ of the total FLW and poultry accounted for $6 \%$ of the total FLW-associated GHG emissions. Thus, these food categories are also important food items to be considered for FLW reduction.

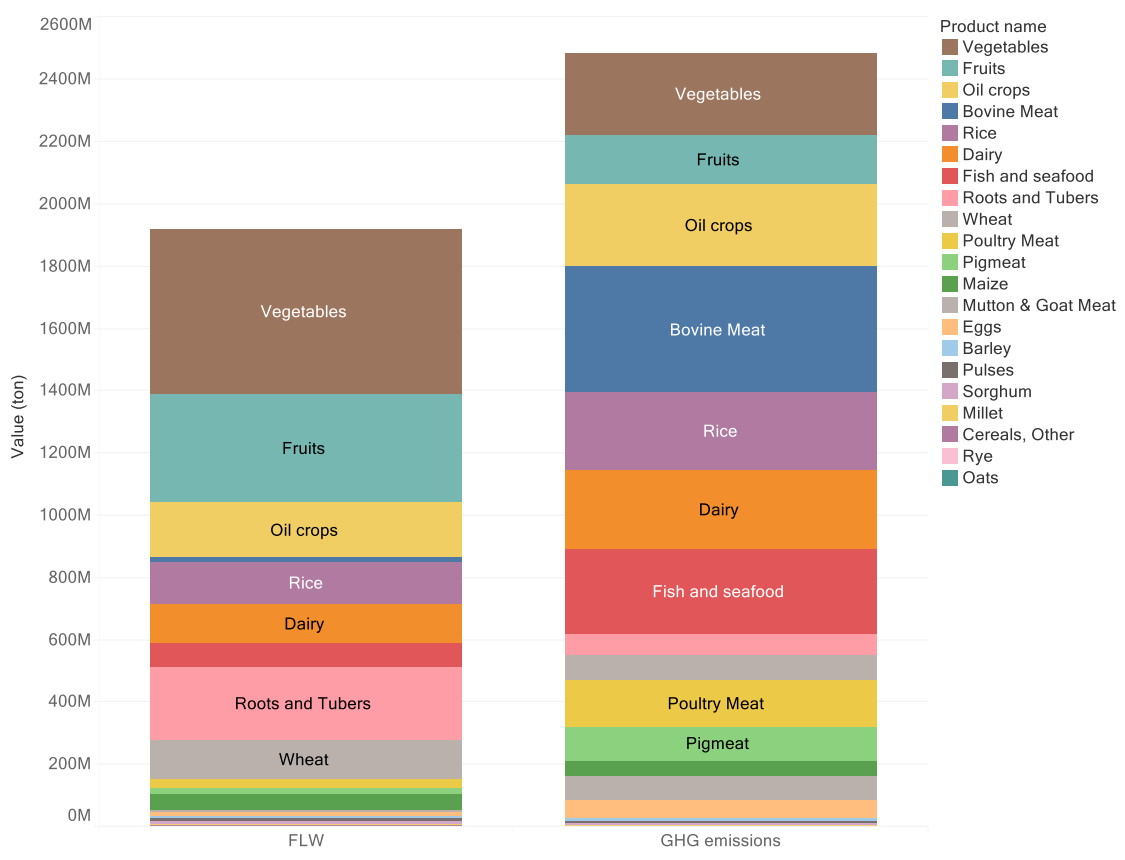

Figure 3. Global hotspots for FLW and associated GHG emissions in 2017.

Figure 4 demonstrates the global hotspots overview by the chain stage. In general, primary production and consumer stages yielded slightly higher FLW and associated GHG emissions than the storage and handling and food distribution stages. The processing stage generated much lower FLW and associated GHG emissions compared to other stages. Specific to food items, it shows that bovine meat was responsible for the highest FLW-associated GHG emissions in the consumer stage. FLW for vegetables and fruits was prominent for all chain stages except for processing. FLW for roots and tubers mainly occurred in the primary production and storage and handling stage. On the other hand, dairy 
FLW happened more in the food distribution and consumer stages. Oil crops (including soybeans) are the major source of FLW and associated GHG emissions in the processing stage. Mutton and goat meat pops up as a high emission item associated with FLW in the primary production stage but remains insignificant in other stages.

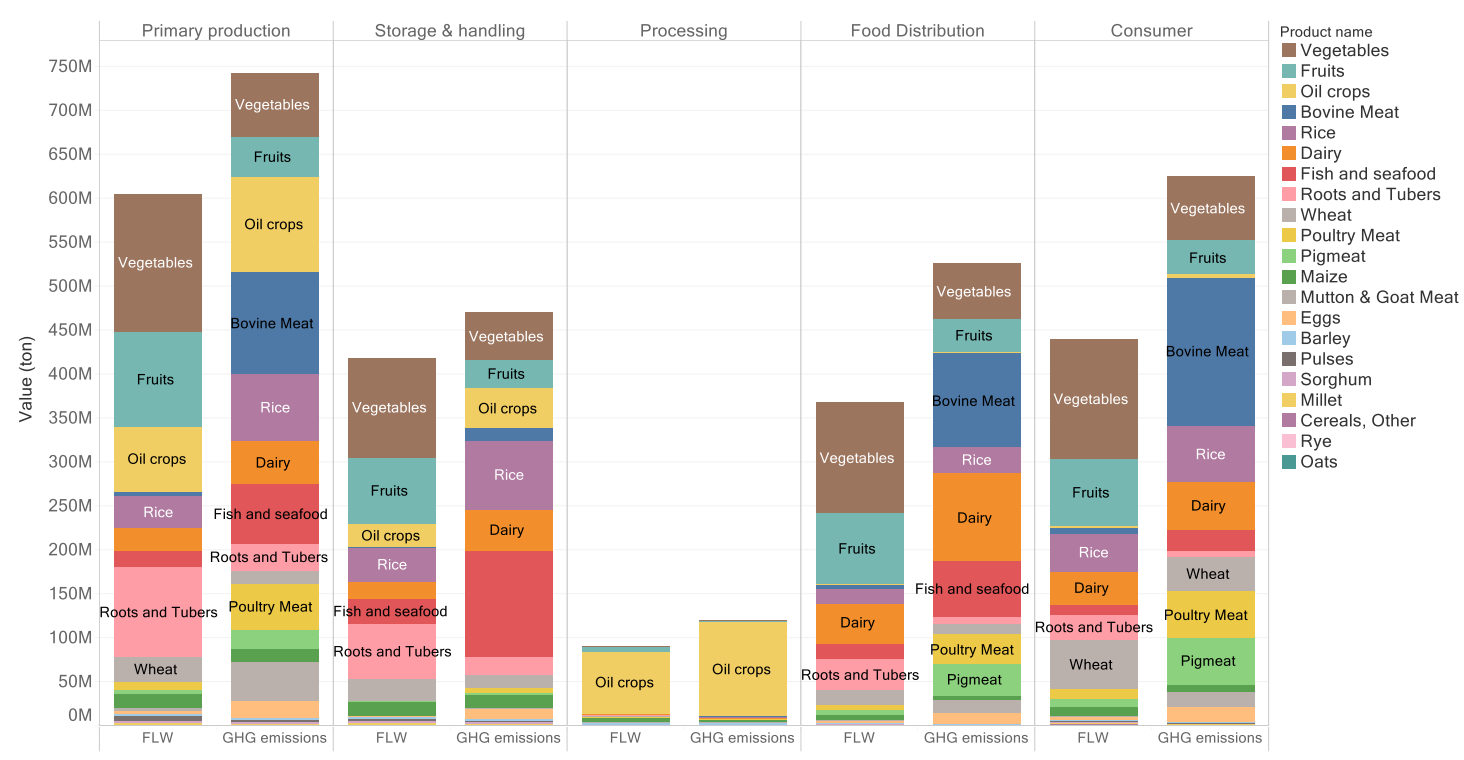

Figure 4. Global hotspots for FLW and associated GHG emissions by chain stage in 2017.

FAO has grouped the countries of the world into seven region categories based on their relative development phases. The countries within a region category are expected to have a comparable stage of development, natural conditions, and climate; therefore, it is expected that they feature comparable FLW percentages and primary-production-phase GHG emission factors. The seven regions are: Europe; Industrialized Asia; Latin America; North Africa, West and Central Asia; North America and Oceania; South and South-East Asia; Sub-Saharan Africa. The previous comprehensive studies in this field used those regions as references as well (e.g., Gustavsson, Cederberg, Sonesson, van Otterdijk and Meybeck [34], Porter, Reay, Higgins and Bomberg [13]).

Figure 5 indicates that Industrialized Asia generated the largest volumes of FLW and South and South-East Asia generated the highest FLW-associated GHG emissions. Through zooming into different supply chain stages, as shown in Figure 6, we can see that Industrialized Asia and South and South-East Asia were dominating FLW and associated GHG emissions at all but the consumer stage. In the consumer stage, FLW of Europe was larger than that of South and South-East Asia, and the FLW-associated GHG emissions of North America and Oceania were the largest among the seven regions. The top 10 countries are presented in Figure 7, which accounted for approximately $60 \%$ of the global FLW and associated GHG emissions. China was the one with the largest FLW and associated GHG emissions globally. It was followed by India and the United States. 


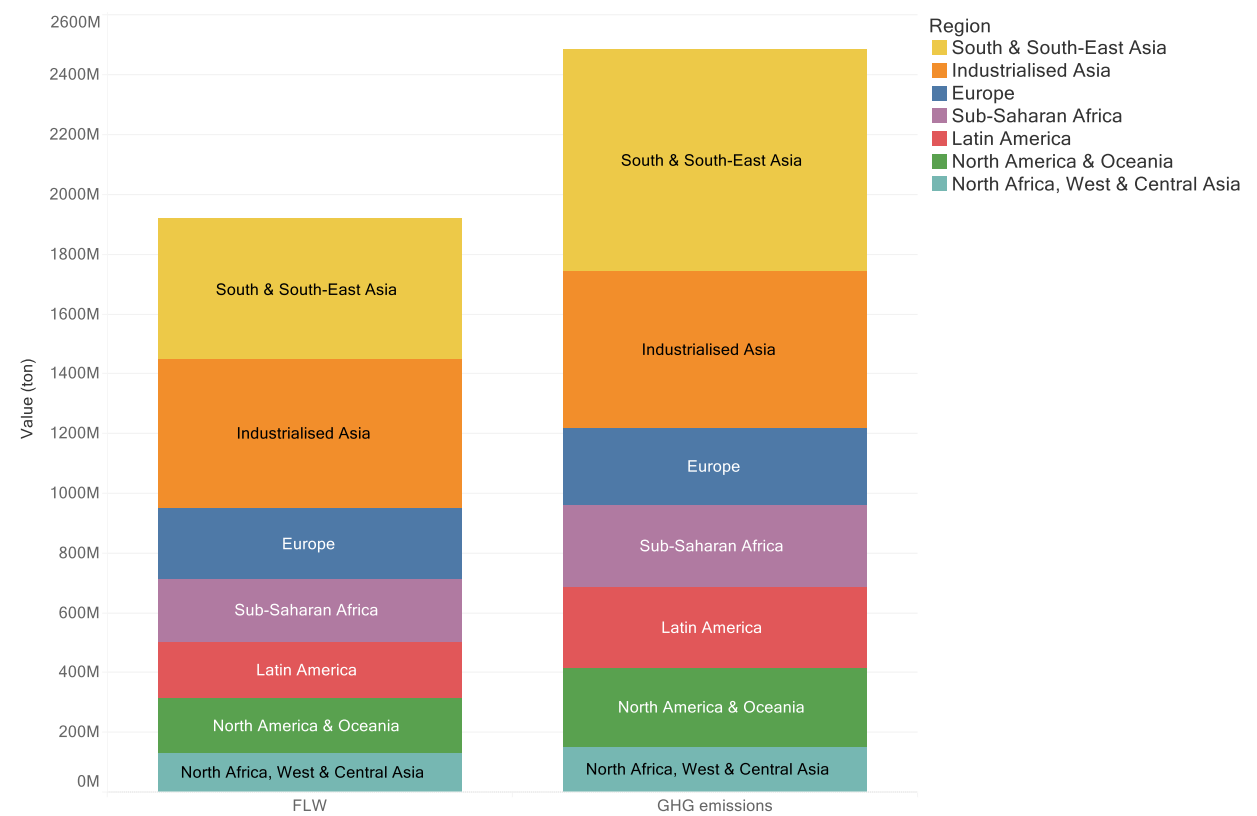

Figure 5. The overview of FLW and associated GHG emissions for FAO-defined regions in 2017.

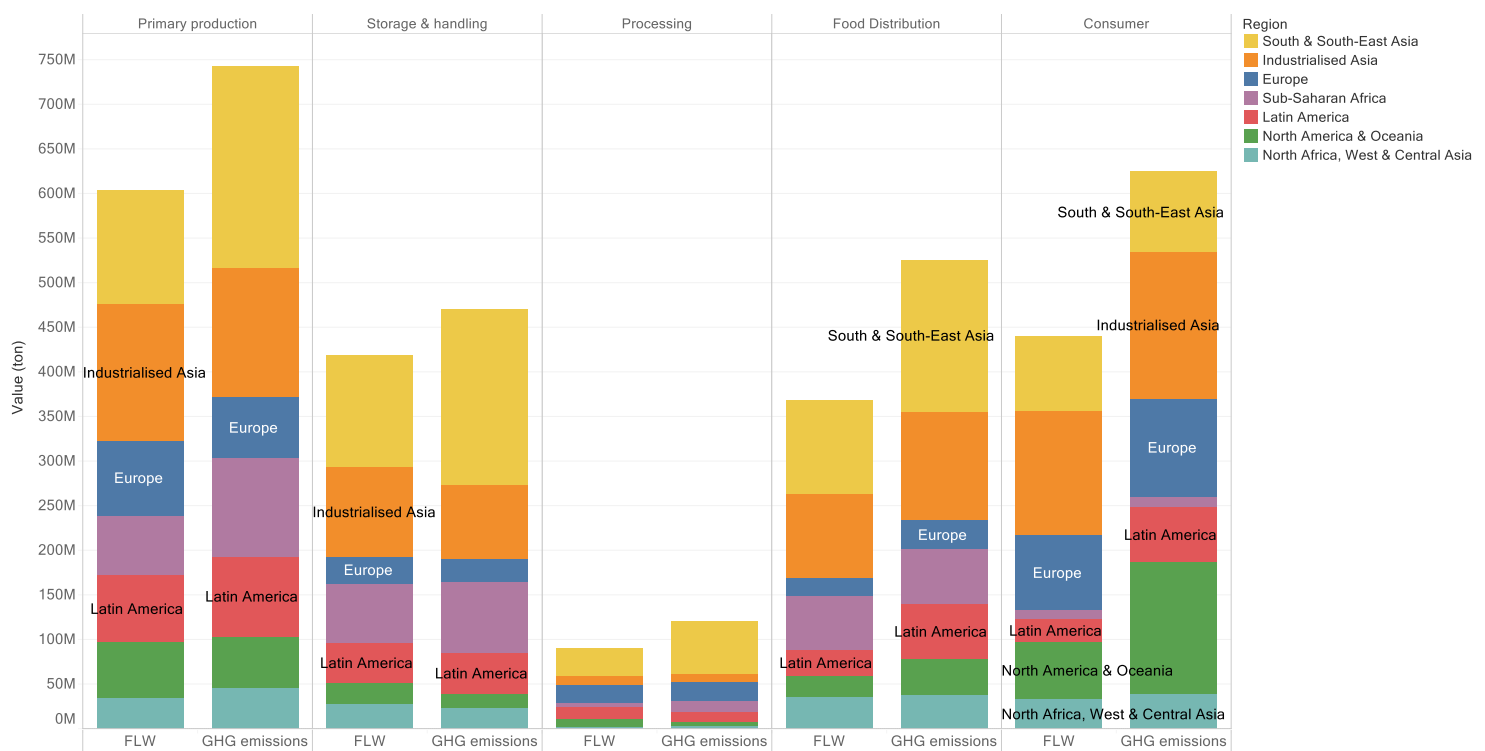

Figure 6. The overview of FLW and associated GHG emissions for FAO-defined regions by chain stage in 2017. 


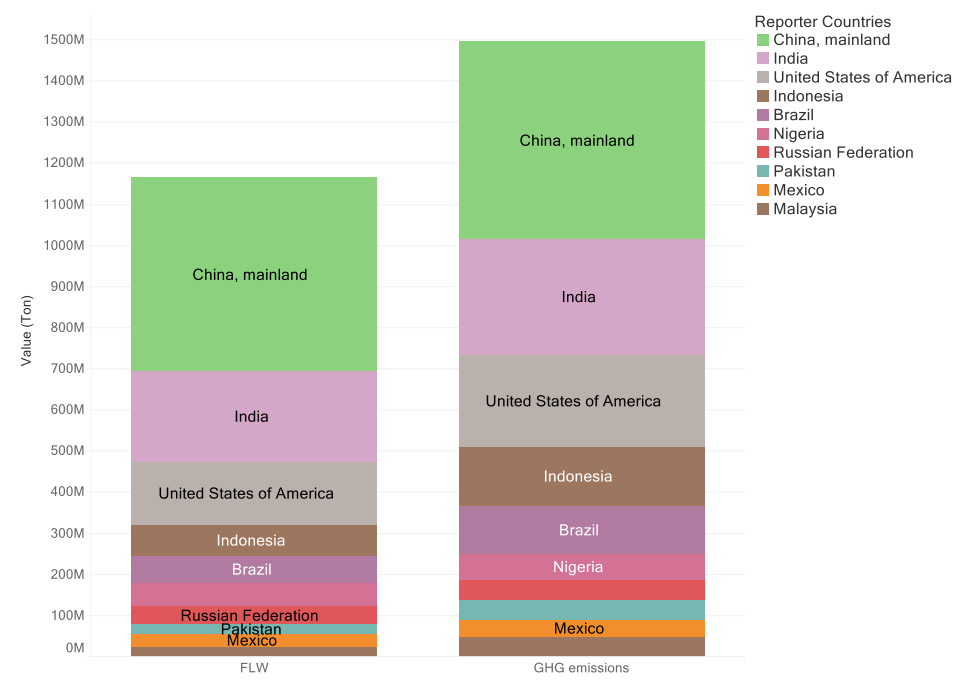

Figure 7. The top 10 countries in the world that generated the most FLW and associated GHG emissions in 2017.

Figures 8-14 present region-based overviews for the seven FAO-defined regions, specified to the distinguished chain stages. The values shown in the graphs are the per-capita values ( $\mathrm{kg} /$ person) to eliminate the effect of population size and make the figures more comparable.

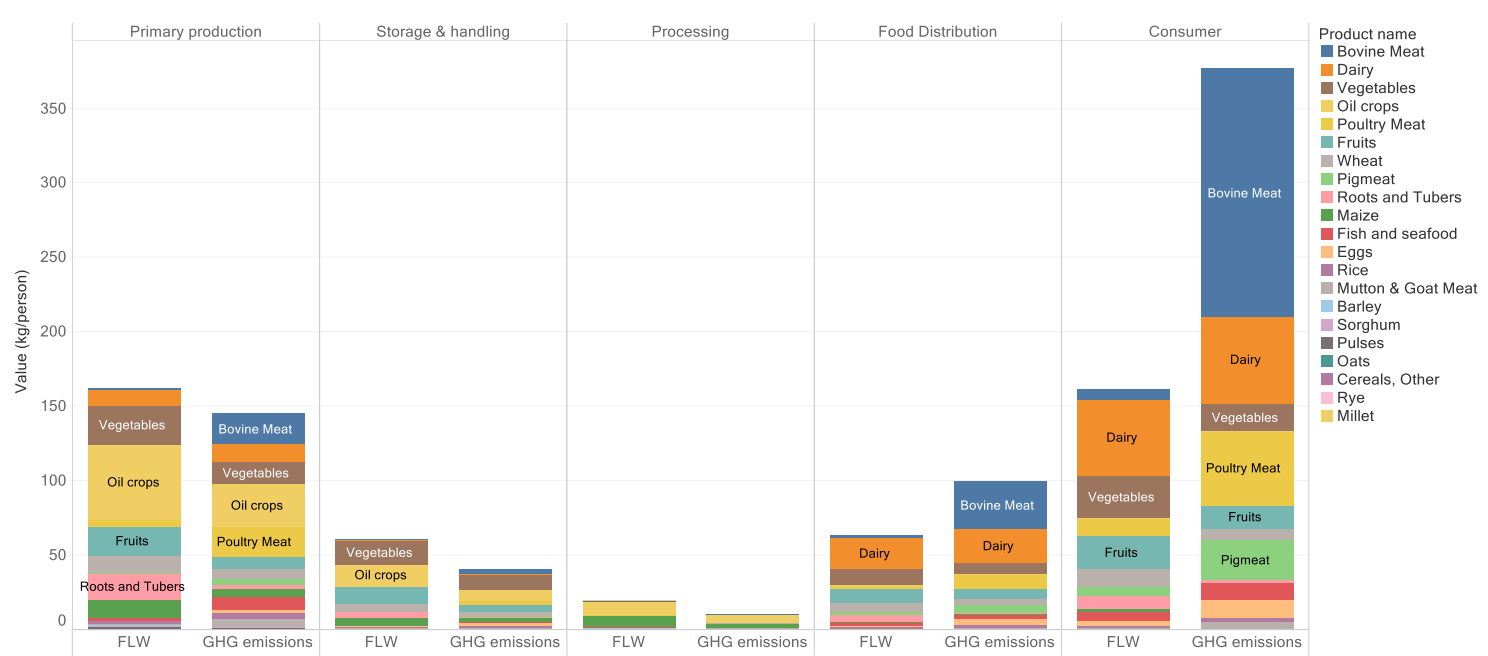

Figure 8. FLW and associated GHG emissions for North America and Oceania by chain stage in 2017. 


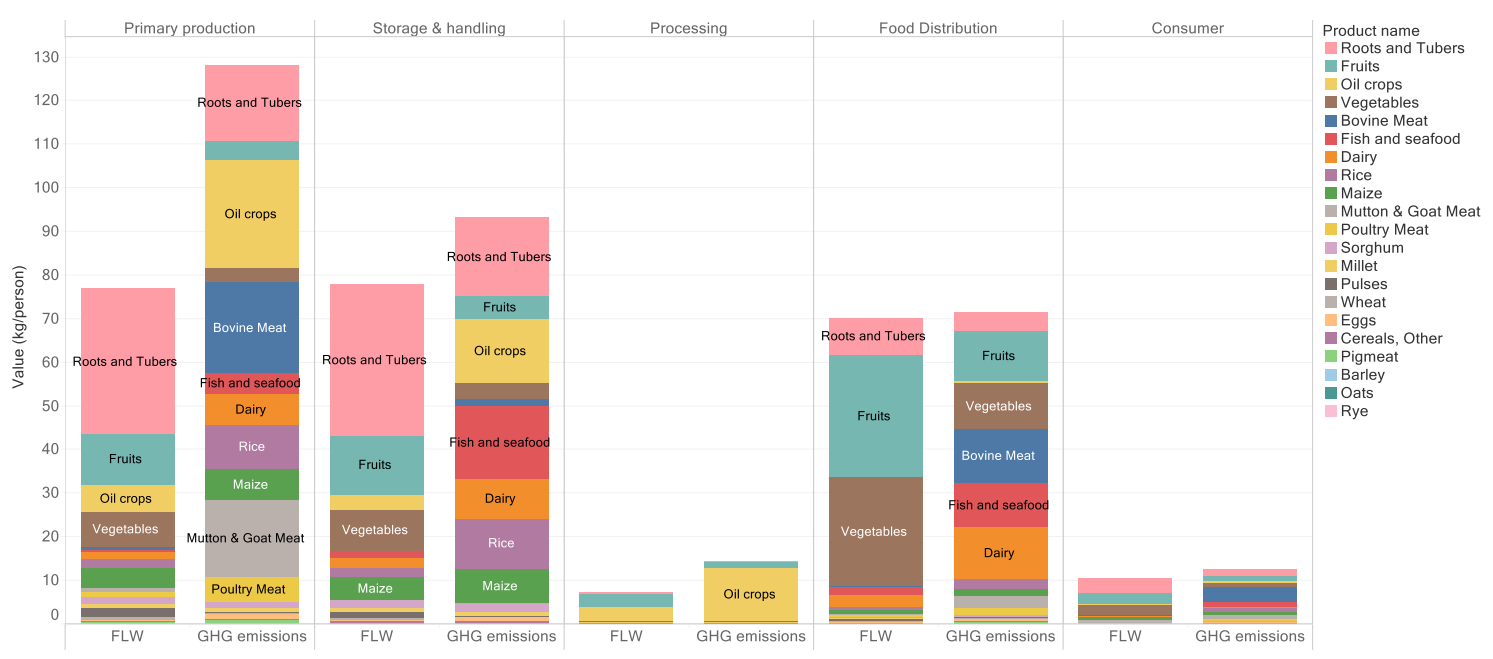

Figure 9. FLW and associated GHG emissions for Sub-Saharan Africa by chain stage in 2017.

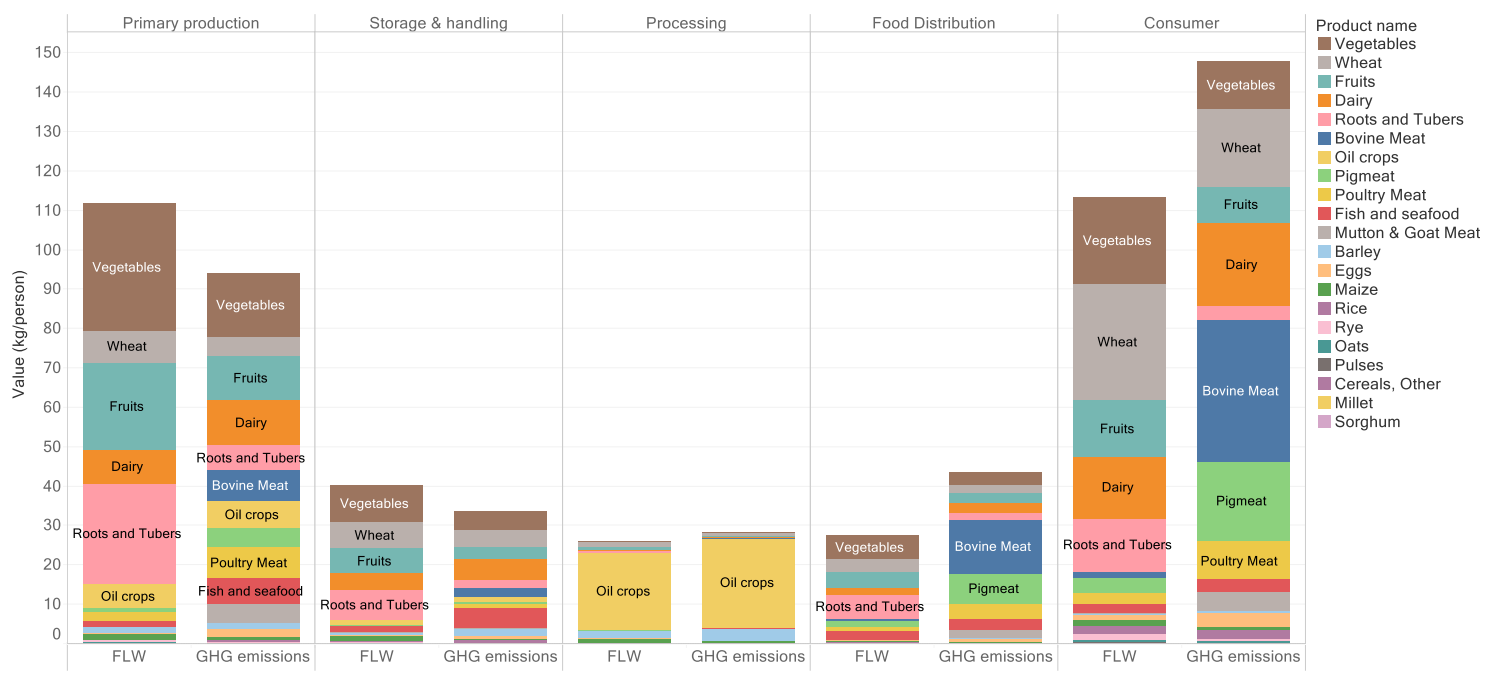

Figure 10. FLW and associated GHG emissions for Europe by chain stage in 2017.

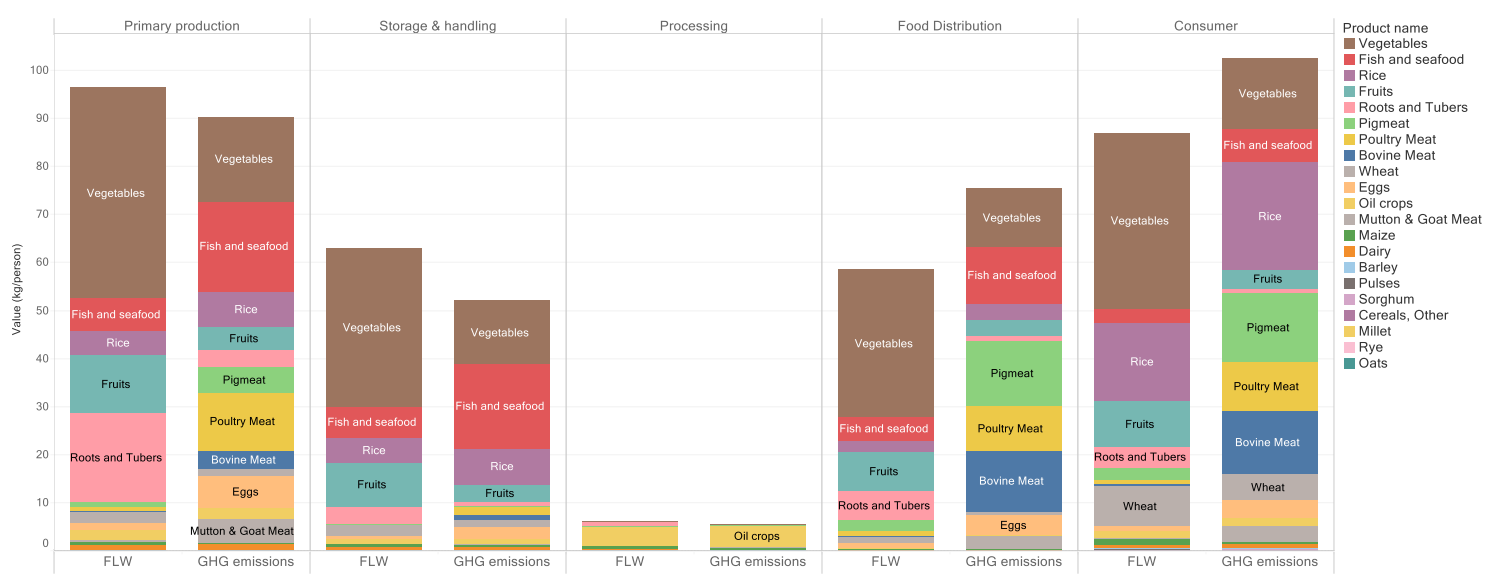

Figure 11. FLW and associated GHG emissions for Industrialized Asia by chain stage in 2017. 


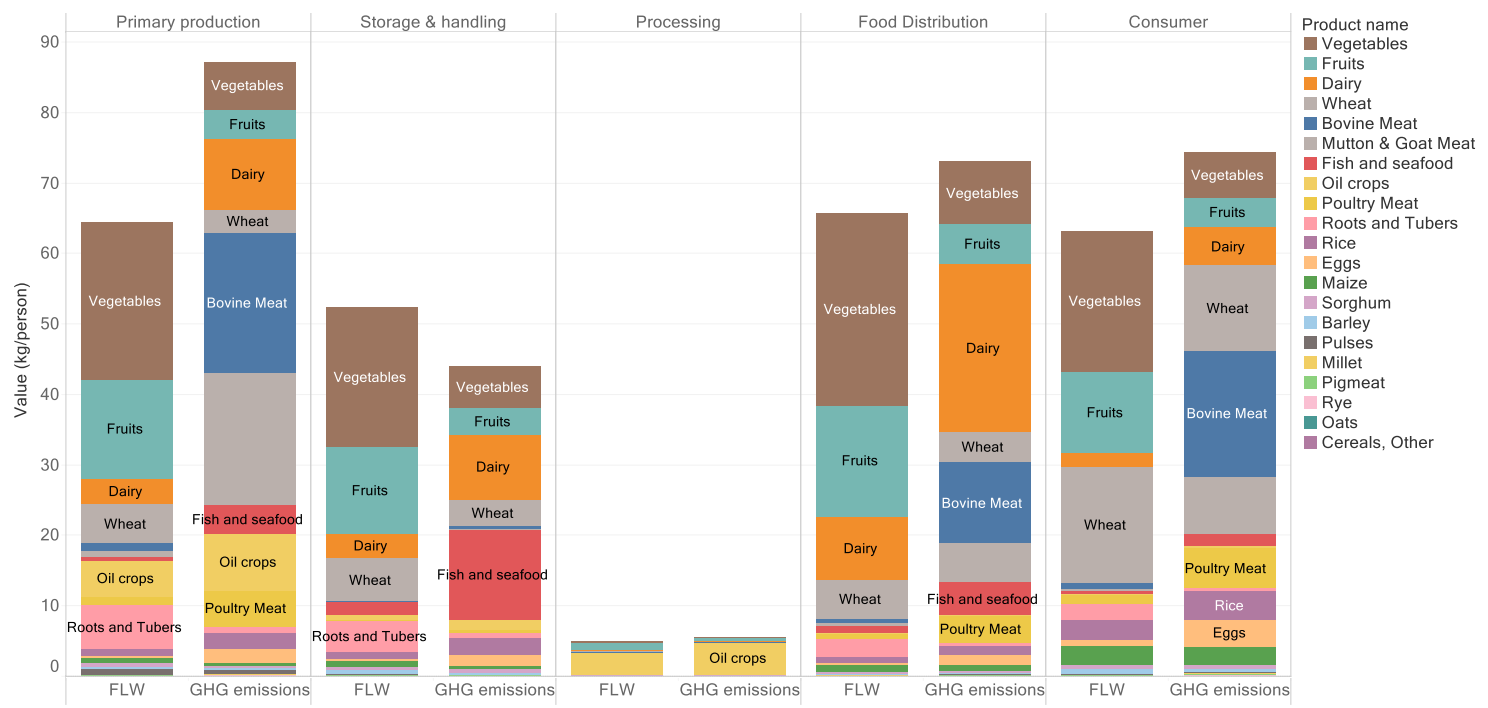

Figure 12. FLW and associated GHG emissions for North Africa, West and Central Asia by chain stage in 2017.

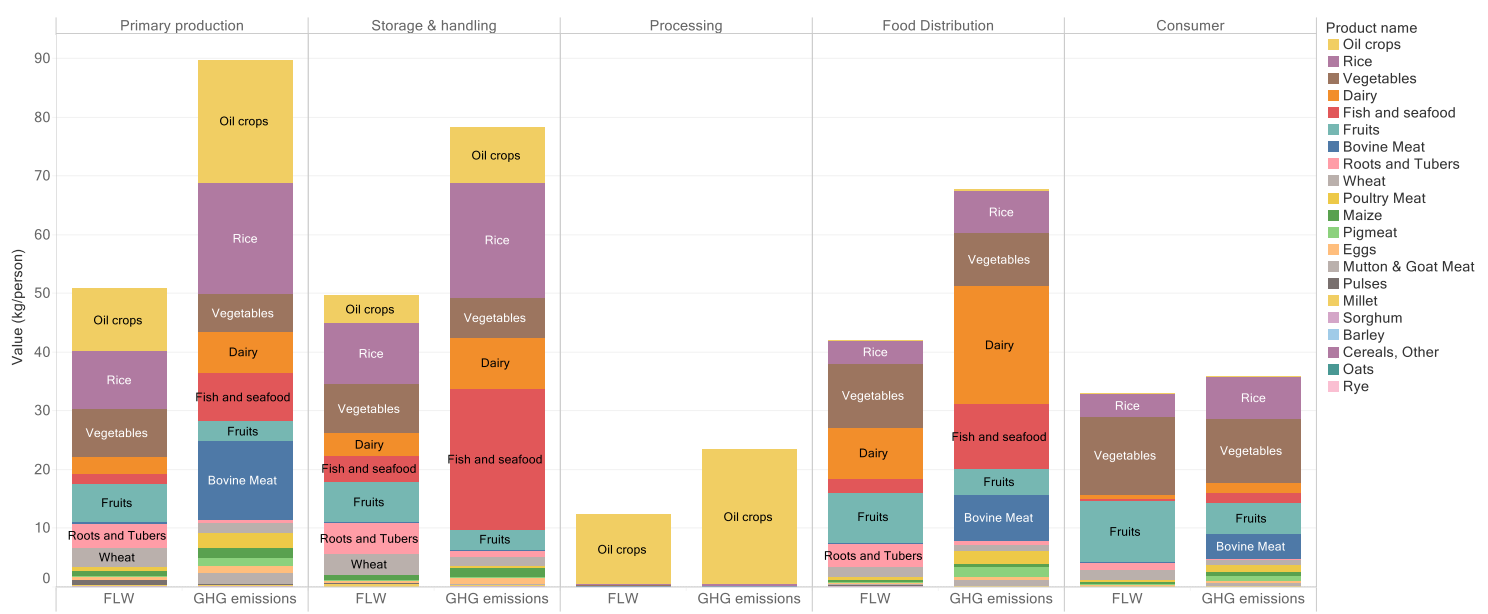

Figure 13. FLW and associated GHG emissions for South and South-East Asia by chain stage in 2017.

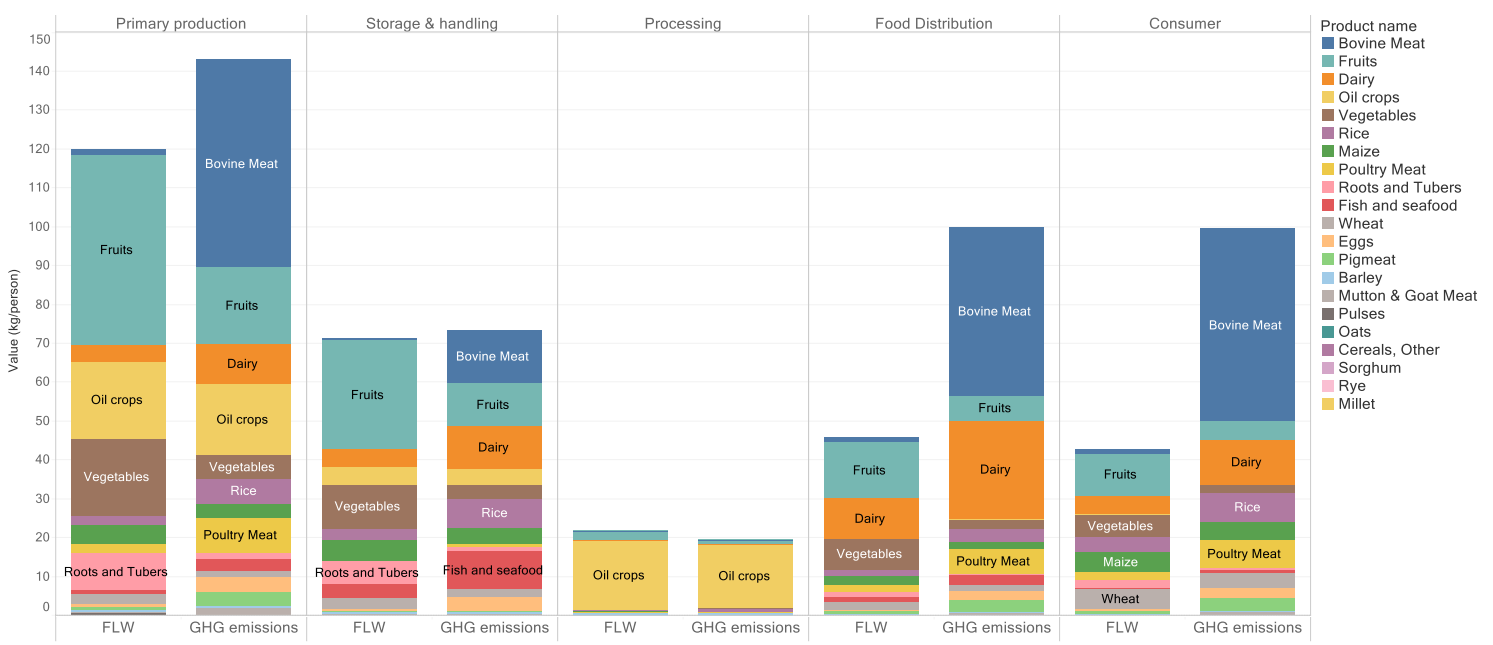

Figure 14. FLW and associated GHG emissions for Latin America by chain stage in 2017. 
Figures 8 and 9 show that North America and Oceania generated much more per-capita FLW in the primary production and consumer stages than Sub-Saharan Africa. For other stages including storage and handling, processing, and food distribution, Sub-Saharan Africa had more FLW than North America and Oceania. Another prominent observation in Figure 8 is that bovine meat accounted for $44 \%$ of the FLW-associated GHG emissions in the consumer stage of North America and Oceania, and combined with dairy, the ruminants-related number becomes $60 \%$. FLW of roots and tubers for Sub-Saharan Africa was significant in the primary production and storage and handling stages, while for fruits and vegetables, it was prominent in the food distribution stage.

Although both are developed areas, as shown in Figure 10, Europe generated less FLW than North America and Oceania in almost all supply chain stages. Moreover, wheat in the consumer stage of Europe popped up as a high-FLW item, reflecting the large wastage of bread in European households. Furthermore, the same pattern of stage-specific FLW in North America and Oceania is observed.

Significant amounts of vegetables were wasted in Industrialized Asia, followed by fish and seafood, rice, and fruits, as shown in Figure 11. Vegetables, dairy, and fruit are also the major contributors to FLW and the associated GHG emissions in North Africa, West and Central Asia, as shown in Figure 12. For Latin America, fruits become the major source of FLW and the importance of vegetables drops notably, as shown in Figure 14. Bovine meat plays a dominating role in generating FLW-associated GHG emissions in Latin America. Oil crops and rice are the top two contributors in South and South-East Asia, as shown in Figure 13.

\subsection{Protein Losses}

Protein losses associated with food losses are an important issue related to food security because protein is the essential nutrient to build up human bodies and assure a healthy life. In terms of the FLW-associated protein losses at the global scale, oil crops (including soybeans) and wheat are the top two items, followed by vegetables, rice, and fish and seafood, as shown in Figure 15. Here, it looks a bit surprising that not all the protein crops (such as pulses) are the hotspot items. The reason is that the total protein losses for a specific item are determined by both the content of protein and the mass of FLW. Since the FLW for pulses is very small, as shown in Figure 3, even though they contain high protein content, the total protein losses are still relatively low. Compared to Figure 3, the importance of fruits and vegetables becomes lower due to the low protein content.

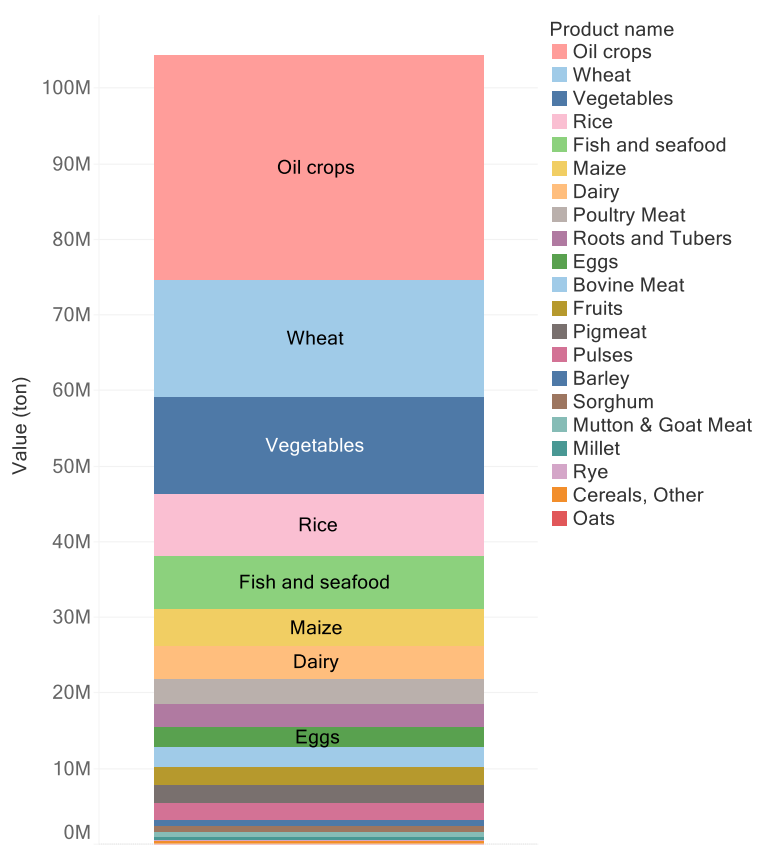

Figure 15. Global protein losses associated with the FLW in 2017. 
Looking into the different stages of the global food chains, as shown in Figure 16, the protein losses associated with oil crops mainly occurred in the primary production and processing stages. The wheat-related protein losses happened mostly in the consumer stage. This is contrary to the overview in Figure 4, where the FLW for the top two items (i.e., fruits and vegetables) are quite evenly distributed in all chain stages except for processing. Oil crops are the hotspots in the processing stage in terms of FLW, the associated GHG emissions, and protein losses.

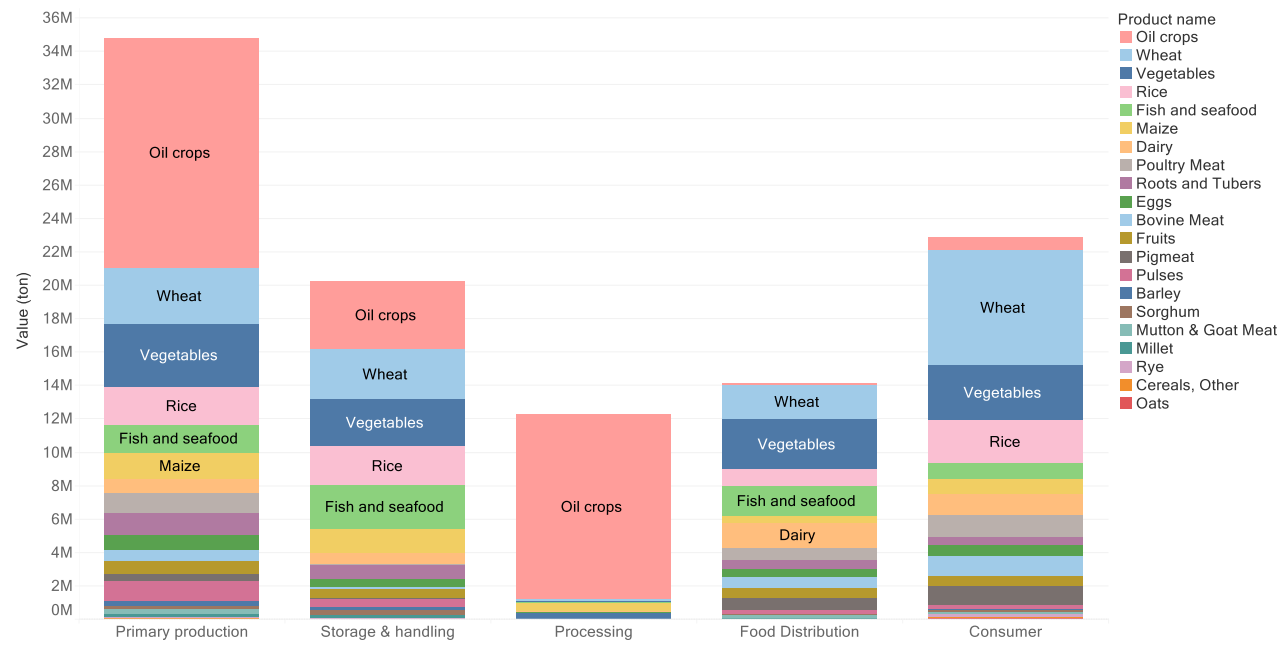

Figure 16. Global protein losses associated with the FLW by chain stage in 2017.

If zooming into the seven regions, we can see that the largest protein losses in 2017 for North America and Oceania and Latin America were from oil crops and concentrated in the primary production, storage and handling, and processing stages, as shown in Figures 17 and 18. Bovine meat, the dominating item for GHG emissions, as shown in Figure 8, becomes a minor source for protein losses. It is even less important than poultry meat. The same chain-wise distribution pattern for the oil crops in North America and Oceania and Latin America was observed in Sub-Saharan Africa but with smaller magnitudes, as shown in Figure 19. Maize was the second-largest source for protein losses in Sub-Saharan Africa, while it contributes a very small amount to the FLW and associated GHG emissions, as shown in Figure 9. For Europe, wheat takes over the position of the oil crops and becomes the largest source, especially in the consumer stage, as shown in Figure 20. This is in line with its importance in terms of FLW and associated GHG emissions, ranking second on the list, as shown in Figure 10. The chain-wise distribution of wheat-related protein losses in North Africa, West and Central Asia shows a similar pattern as in Europe, as shown in Figure 21. For Industrialized Asia, oil crops' position is replaced by vegetables as the number one item with the highest protein losses, as shown in Figure 22. This is because vegetables are the dominating source for FLW in Industrialized Asia, as shown in Figure 11. Rice and wheat are the top two sources for protein losses in South and South-East Asia, as shown in Figure 23, while the top two items for FLW and associated GHG emissions are oil crops and rice, as shown in Figure 13. 


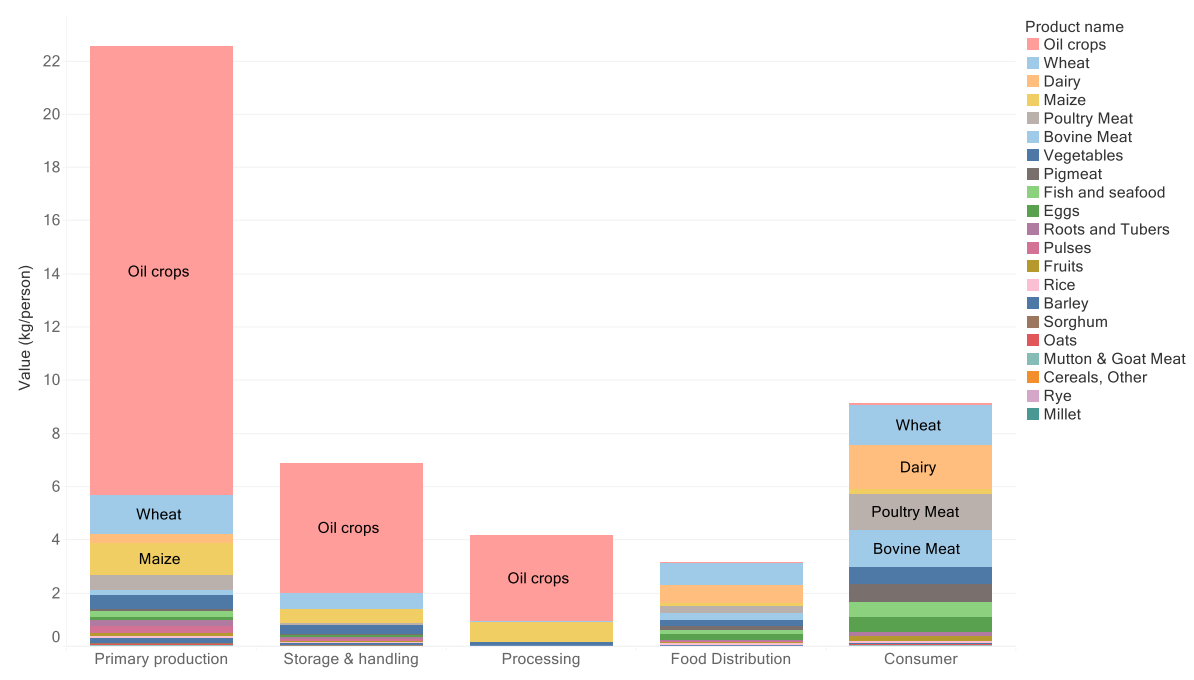

Figure 17. The protein losses associated with the FLW by chain stage in North America and Oceania in 2017.
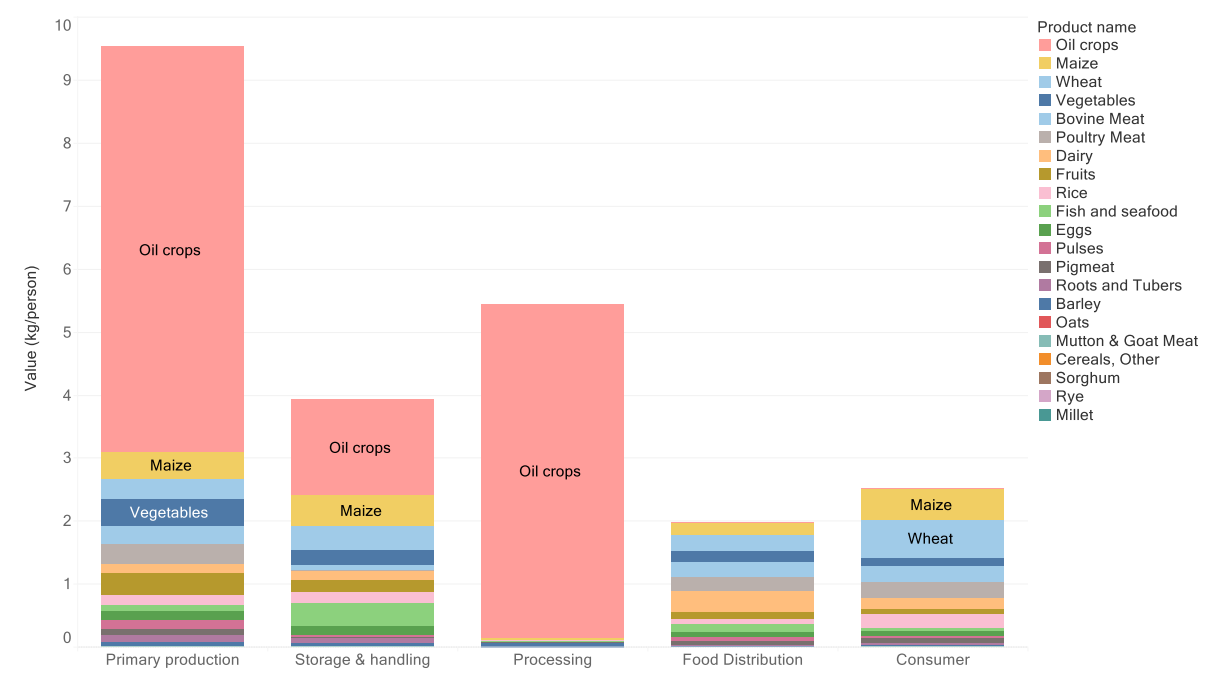

Figure 18. The protein losses associated with the FLW by chain stage in Latin America in 2017.
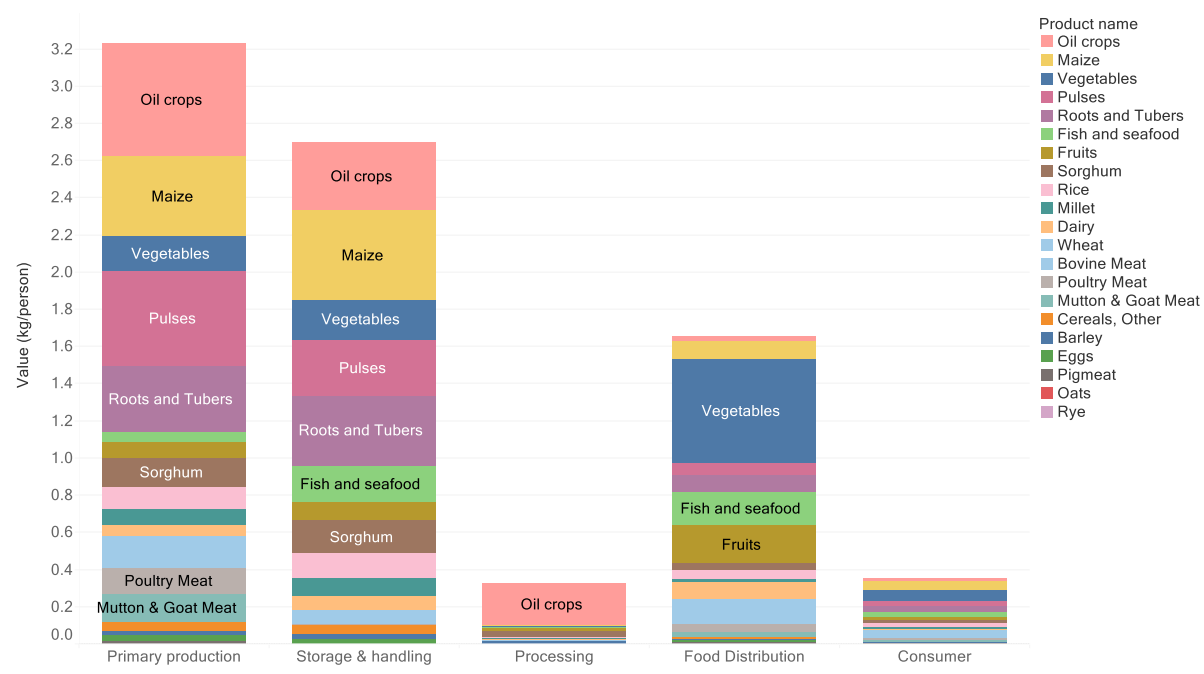

Figure 19. The protein losses associated with the FLW by chain stage in Sub-Saharan Africa in 2017. 


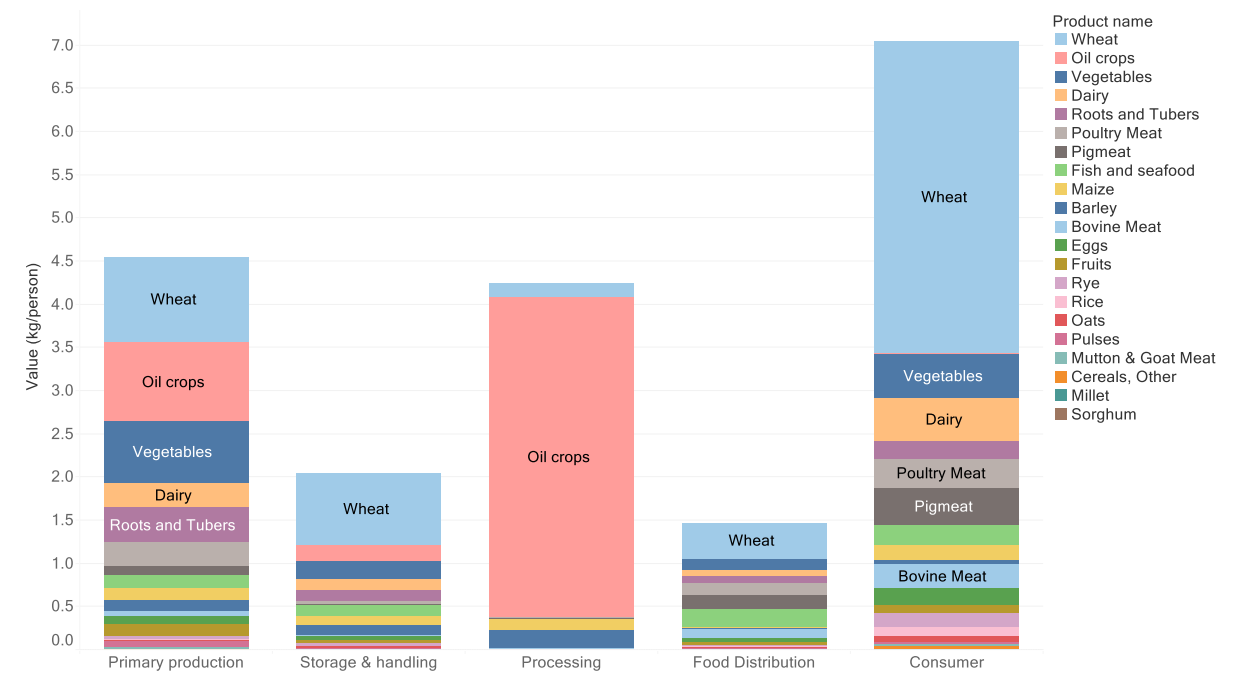

Figure 20. The protein losses associated with the FLW by chain stage in Europe in 2017.

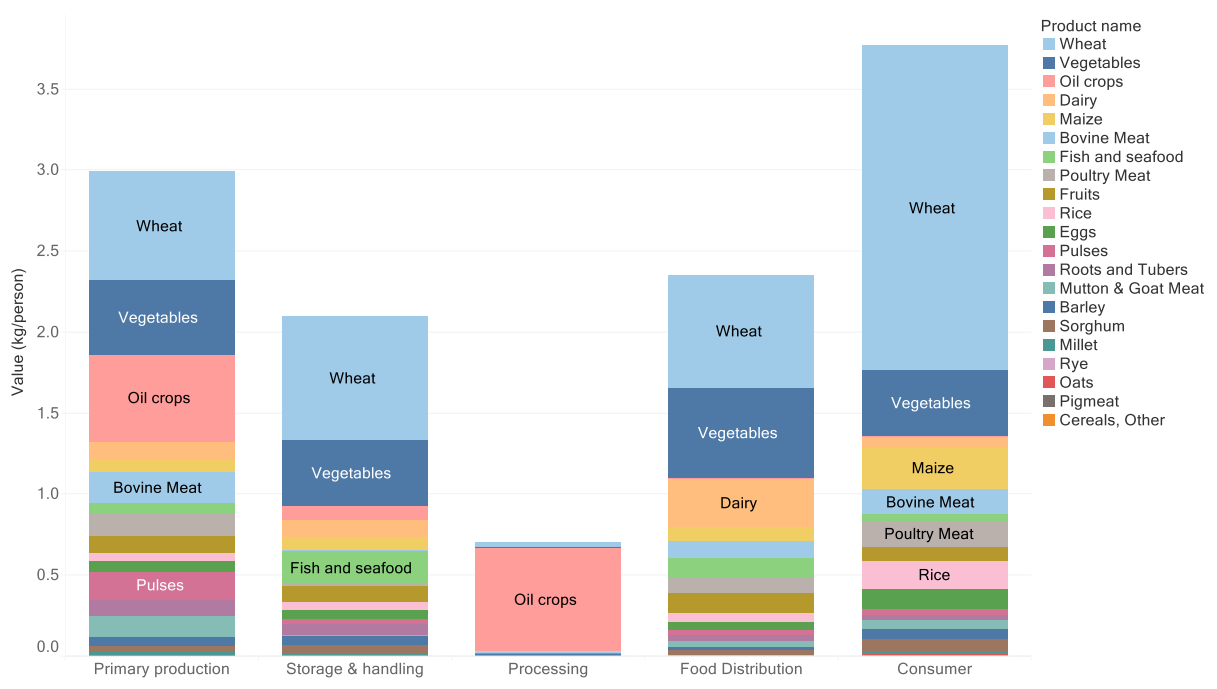

Figure 21. The protein losses associated with the FLW by chain stage in North Africa, West and Central Asia in 2017.

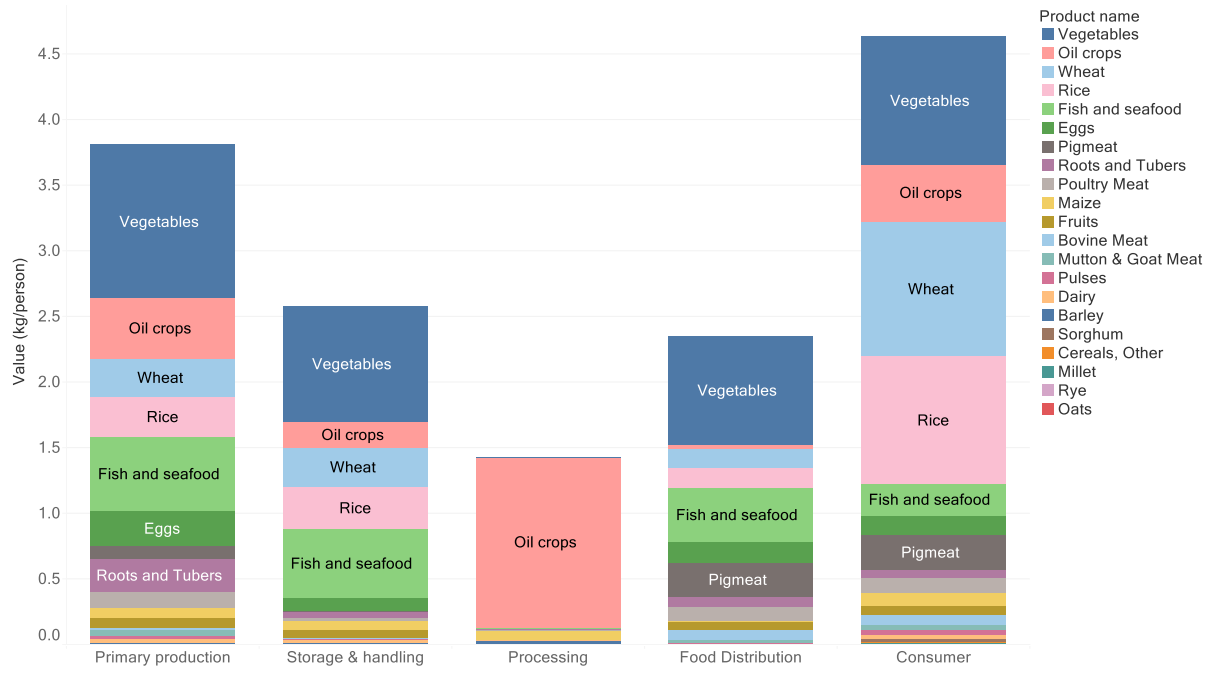

Figure 22. The protein losses associated with the FLW by chain stage in Industrialized Asia in 2017. 

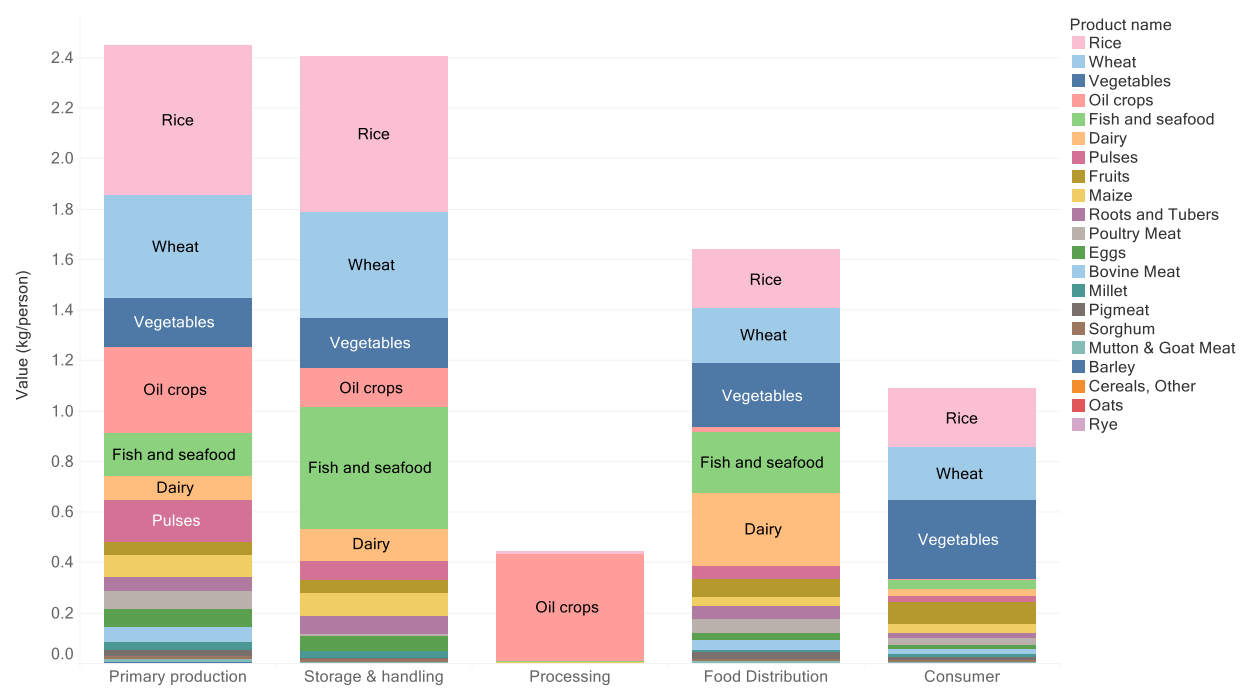

Figure 23. The protein losses associated with the FLW by chain stage in South and South-East Asia in 2017.

\section{Discussion}

In this research, we conducted a global hotspot analysis by quantifying the FLW as well as the associated GHG emissions and protein losses. Different from the traditional climate-smart agriculture viewpoint, we adopted the prospect of climate-smart food chains. This research is of high significance because of the fast-growing world population with more middle classes favoring higher-income dietary patterns. It requires more fresh and nutritional food supplies (e.g., fresh fruit and vegetables, milk, meat, oil crops). Those are responsible for large amounts of FLW associated with huge GHG emissions and protein losses, as well as other nutrients. The hotspot analysis can help the policymakers identify the crops and animal products that have the highest potentials on FLW. It therefore contributes to food and nutrition security, as well as climate change mitigation.

\subsection{Conclusions and Implications}

The total values on FLW and associated GHG emissions are quite comparable to other studies. The computed global FLW in this research is equal to $1.9 \mathrm{Gt}$ for 2017. This complies with the $1.6 \mathrm{Gt}$ for 2011 calculated by Porter, Reay, Higgins and Bomberg [13], taking the different years in use into account. The calculated FLW accounts for $29 \%$ of the total primary food production. This is in line with the widely accepted concept that roughly a quarter to one-third of the food produced in the world is lost or wasted based on the research of Gustavsson, Cederberg, Sonesson, van Otterdijk and Meybeck [34] and others. The total calculated FLW-associated GHG emissions in 2017 equals $2.5 \mathrm{Gt}$, which also makes sense compared to $2.2 \mathrm{Gt}$ in 2011 estimated by Porter, Reay, Higgins and Bomberg [13].

Specific to the food items, fruits and vegetables are the major contributors to global FLW. Bovine meat leads to significant FLW-associated GHG emissions, especially in the consumer stage of North America and Oceania (i.e., GHG emission footprint of the FLW at the consumer level considering the emissions from the primary production activities and international food transportation). Moreover, oil crops are the dominating source of protein losses. The different hotspots identified by different criteria underpin the importance of addressing the FLW issues from various aspects of sustainability. Namely, from the point of view of reducing GHG emissions, policymakers should focus on designing intervention strategies to reduce beef consumption; however, from a nutrient perspective, it is more sensible to put more resources in reducing the losses for oil crops. The policymakers therefore should make a balanced plan considering the trade-offs between different intervention points given the intervention resources are limited. 
The total GHG emissions due to international food transportation are marginal compared to the primary production-related GHG emissions. This confirms the alleged dominating role for primary production in GHG emissions of the global food system. For example, Hamerschlag and Venkat [40] indicated that the primary-production-phase GHG emissions for meat products including beef, lamb, pork, and poultry account for $50 \%$ to $90 \%$ of the full-life GHG emissions. For the non-meat products, including milled cereals, dairy, and various types of fruits and vegetables, the percentages are between $60 \%$ to $85 \%$ [41-43]. Scherhaufer, Lebersorger, Pertl, Obersteiner, Schneider, Falasconi, De Menna, Vittuari, Hartikainen and Katajajuuri [39] demonstrated that for the EU countries, the primary-production-phase GHG emissions are as much as $93 \%$ of the full-life GHG emissions for beef. As to other animal products, the percentages are $78 \%, 75 \%, 64 \%$, and $63 \%$ for milk, pork, fish, and chicken, respectively. The number is $86 \%$ for the greenhouse-grown tomatoes and $60 \%$ for bread.

In the aforementioned primarily animal-related data, the high emission factor of the agricultural production is dominant. As the opposite, in plant-based products, with much lower crop emission factors, post-harvest operations have relatively large contributions and therefore deserve close attention. However, owing to the diverse characteristics of post-harvest chains and the lack of relevant data, we have not yet included them into our calculations.

\subsection{Limitations and Future Research}

There are also limitations to this study. Firstly, the data used for the hotspot analysis are secondary data. They may have relatively low accuracy compared to the primary data from direct measurement. The used information from FAO Food Balance Sheets is not amazingly accurate, particularly for developing countries where data along the supply chain have limitations. Secondly, the used FLW percentages are based on FAO-defined regions because those are by far the most complete data available to conduct global and super-national studies. However, within these regions, there could be still some variations between different countries. For example, for Industrialized Asia, the same FLW percentages were applied to Japan, South Korea, and China, which should actually be deviated in reality. For example, the fruit and vegetable post-harvest losses for China (widely believed between $20 \%$ and $30 \%$ ) should be much higher than those in Japan and South Korea due to the much poorer cold chain infrastructure in China. The same issue also applies to the region-based GHG emission factors. Thirdly, the FLW percentages are aggregated for some food product groups in Porter, Reay, Higgins and Bomberg [13]. For example, all the fruits and vegetables share one set of FLW percentages. This could cause some levels of inaccuracy when there are big variations between different fruit and vegetable products (e.g., the on-farm losses for apples could be much lower than that for strawberries).

Future research should focus on generating more national-level data on FLW percentages and GHG emission factors, preferably through more frequent field surveys within individual countries. This can enable the country-specific analysis of the identification of hotspots. When the primary data are not available, smart use of the secondary data with careful validation is required. It would be desirable to have the FLW percentages and GHG emission factors at the specific product level instead of the aggregated product group level. Moreover, to have the GHG emission factors for the full life cycles of products will make the calculation on FLW-associated GHG emissions more complete. It should, therefore, be a future research direction to go as well.

Author Contributions: Conceptualization, X.G., J.B., M.V. and H.A.; methodology, X.G., J.B. and J.J.G.; software, X.G. and J.J.G.; formal analysis, X.G.; data curation, X.G., J.J.G. and J.B.; writing-original draft preparation, X.G.; writing-review and editing, J.B., M.V., H.A. and J.J.G.; visualization, X.G.; project administration, H.A. All authors have read and agreed to the published version of the manuscript.

Funding: CGIAR Research Program on Climate Change, Agriculture and Food Security (CCAFS).

Acknowledgments: This work was implemented as part of the CGIAR Research Program on Climate Change, Agriculture and Food Security (CCAFS), which is carried out with support from CGIAR Fund Donors and through bilateral funding agreements. For details please visit https://ccafs.cgiar.org/donors. The views expressed in this document cannot be taken to reflect the official opinions of these organizations. 
Conflicts of Interest: The authors declare no conflict of interest.

\section{References}

1. FAO. Global Agriculture towards 2050; FAO: Rome, Italy, 2009.

2. Fiore, M.; Contò, F.; Pellegrini, G. Reducing food losses: A (dis)-opportunity cost model. Riv. Di Studi Sulla Sostenibilita 2015, 1. [CrossRef]

3. Fiore, M.; Pellegrini, G.; Sala, P.L.; Conte, A.; Liu, B. Attitude toward food waste reduction: The case of Italian consumers. Int. J. Glob. Small Bus. 2017, 9, 185-201. [CrossRef]

4. Spada, A.; Conte, A.; Del Nobile, M.A. The influence of shelf life on food waste: A model-based approach by empirical market evidence. J. Clean. Prod. 2018, 172, 3410-3414. [CrossRef]

5. Adamashvili, N.; Chiara, F.; Fiore, M. Food Loss and Waste, a global responsibility?! Econ. Agro Aliment. 2019, 825-846. [CrossRef]

6. Pellegrini, G.; Sillani, S.; Gregori, M.; Spada, A. Household food waste reduction: Italian consumers' analysis for improving food management. Br. Food J. 2019, 121, 1382-1397. [CrossRef]

7. Vittuari, M.; De Menna, F.; García-Herrero, L.; Pagani, M.; Brenes-Peralta, L.; Segrè, A. Chapter 17—Food systems sustainability: The complex challenge of food loss and waste. In Sustainable Food Supply Chains; Accorsi, R., Manzini, R., Eds.; Academic Press: Cambridge, MA, USA, 2019; pp. 249-260.

8. Vittuari, M.; Pagani, M.; Johnson, T.G.; De Menna, F. Impacts and costs of embodied and nutritional energy of food waste in the US food system: Distribution and consumption (Part B). J. Clean. Prod. 2020, 252, 119857. [CrossRef]

9. Pagani, M.; De Menna, F.; Johnson, T.G.; Vittuari, M. Impacts and costs of embodied and nutritional energy of food losses in the US food system: Farming and processing (Part A). J. Clean. Prod. 2020, 244, 118730. [CrossRef]

10. Ishangulyyev, R.; Kim, S.; Lee, S.H. Understanding food loss and waste-Why are we losing and wasting food? Foods 2019, 8, 297. [CrossRef]

11. Springmann, M.; Clark, M.; Mason-D’Croz, D.; Wiebe, K.; Bodirsky, B.L.; Lassaletta, L.; De Vries, W.; Vermeulen, S.J.; Herrero, M.; Carlson, K.M. Options for keeping the food system within environmental limits. Nature 2018, 562, 519-525. [CrossRef]

12. Hiç, C.; Pradhan, P.; Rybski, D.; Kropp, J.P. Food surplus and its climate burdens. Environ. Sci. Technol. 2016, 50, 4269-4277. [CrossRef]

13. Porter, S.D.; Reay, D.S.; Higgins, P.; Bomberg, E. A half-century of production-phase greenhouse gas emissions from food loss \& waste in the global food supply chain. Sci. Total Environ. 2016, 571, 721-729. [PubMed]

14. Quested, T.; Ingle, R.; Parry, A. Household Food and Drink Waste in the United Kingdom 2012; WRAP: London, UK, 2013.

15. Wenlock, R.; Buss, D. Wastage of edible food in the home: A preliminary study. J. Hum. Nutr. 1977, 31, 405-411. [PubMed]

16. Wenlock, R.; Buss, D.; Derry, B.; Dixon, E. Household food wastage in Britain. Br. J. Nutr. 1980, 43, 53-70. [CrossRef] [PubMed]

17. Buzby, J.C.; Hyman, J. Total and per capita value of food loss in the United States. Food Policy 2012, 37, 561-570. [CrossRef]

18. Kantor, L.S.; Lipton, K.; Manchester, A.; Oliveira, V. Estimating and addressing America's food losses. Food Rev. Natl. Food Rev. 1997, 20, 2-12.

19. Xue, L.; Liu, G.; Parfitt, J.; Liu, X.; Van Herpen, E.; Stenmarck, Å.; O’Connor, C.; Östergren, K.; Cheng, S. Missing food, missing data? A critical review of global food losses and food waste data. Environ. Sci. Technol. 2017, 51, 6618-6633. [CrossRef]

20. Kling, W. Food waste in distribution and use. J. Farm Econ. 1943, 25, 848-859. [CrossRef]

21. Harrington, J.M.; Myers, R.A.; Rosenberg, A.A. Wasted fishery resources: Discarded by-catch in the USA. Fish Fish. 2005, 6, 350-361. [CrossRef]

22. Engström, R.; Carlsson-Kanyama, A. Food losses in food service institutions Examples from Sweden. Food Policy 2004, 29, 203-213. [CrossRef]

23. Williams, H.; Wikström, F.; Otterbring, T.; Löfgren, M.; Gustafsson, A. Reasons for household food waste with special attention to packaging. J. Clean. Prod. 2012, 24, 141-148. [CrossRef] 
24. Leal Filho, W.; Kovaleva, M. Food Waste and Sustainable Food Waste Management in the Baltic Sea Region; Springer: Berlin/Heidelberg, Germany, 2015.

25. Hodges, R.J.; Buzby, J.C.; Bennett, B. Postharvest losses and waste in developed and less developed countries: Opportunities to improve resource use. J. Agric. Sci. 2011, 149 (Suppl. S1), 37-45. [CrossRef]

26. Fehr, M.; Romão, D. Measurement of fruit and vegetable losses in Brazil: A case study. Environ. Dev. Sustain. 2001, 3, 253-263. [CrossRef]

27. Jones, T.W. Using Contemporary Archaeology and Applied Anthropology to Understand Food Loss in the American Food System. Ph.D. Thesis, Bureau of Applied Research in Anthropology, University of Arizona, Tucson, AZ, USA, 2004.

28. Loke, M.K.; Leung, P. Quantifying food waste in Hawaii's food supply chain. Waste Manag. Res. 2015, 33, 1076-1083. [CrossRef] [PubMed]

29. Stenmarck, Å.; Jörgen Hanssen, O.; Silvennoinen, K.; Katajajuuri, J.-M.; Werge, M. Initiatives on Prevention of Food Waste in the Retail and Wholesale Trades; Nordic Council of Ministers: Copenhagen, Denmark, 2011.

30. Åhnberg, A.; Strid, I. When Food Turns into Waste-A Study on Practices and Handling of Losses of Fruit and Vegetables and Meat in Willys Södertälje Weda; Swedish University of Agricultural Sciences: Uppsala, Sweden, 2010.

31. Beretta, C.; Stoessel, F.; Baier, U.; Hellweg, S. Quantifying food losses and the potential for reduction in Switzerland. Waste Manag. 2013, 33, 764-773. [CrossRef]

32. Caldeira, C.; De Laurentiis, V.; Corrado, S.; van Holsteijn, F.; Sala, S. Quantification of food waste per product group along the food supply chain in the European Union: A mass flow analysis. Resour. Conserv. Recycl. 2019, 149, 479-488. [CrossRef] [PubMed]

33. Lanfranchi, M.; Giannetto, C.; De Pascale, A. Analysis and models for the reduction of food waste in organized large-scale retail distribution in eastern Sicily. Am. J. Appl. Sci. 2014, 11, 1860. [CrossRef]

34. Gustavsson, J.; Cederberg, C.; Sonesson, U.; van Otterdijk, R.; Meybeck, A. Global food losses and food waste: Extent, causes and prevention. In SAVE FOOD: An Initiative on Food Loss and Waste Reduction; FAO: Rome, Italy, 2011.

35. FAO. Food Wastage Footprint: Impacts on Natural Resources; FAO: Rome, Italy, 2013.

36. FAO. The State of Food and Agriculture: Moving Forward on Food Loss and Waste Reduction; FAO: Rome, Italy, 2019.

37. FAO. Food Loss Index. Online Statistical Working System for Loss Calculations. 2019. Available online: http://www.fao.org/food-loss-and-food-waste/flw-data) (accessed on 19 July 2020).

38. Alexander, P.; Brown, C.; Arneth, A.; Finnigan, J.; Moran, D.; Rounsevell, M.D. Losses, inefficiencies and waste in the global food system. Agric. Syst. 2017, 153, 190-200. [CrossRef]

39. Scherhaufer, S.; Lebersorger, S.; Pertl, A.; Obersteiner, G.; Schneider, F.; Falasconi, L.; De Menna, F.; Vittuari, M.; Hartikainen, H.; Katajajuuri, J.-M. Criteria for and Baseline Assessment of Environmental and Socio-Economic Impacts of Food Waste; BOKU University of Natural Resources and Life Sciences, Institute of Waste Management: Vienna, Austria, 2015.

40. Hamerschlag, K.; Venkat, K. Meat Eater's Guide to Climate Change+ Health: Lifecycle Assessments: Methodology and Results 2011; Environmental Working Group: Washington, DC, USA, 2011.

41. Cellura, M.; Longo, S.; Mistretta, M. Life Cycle Assessment (LCA) of protected crops: An Italian case study. J. Clean. Prod. 2012, 28, 56-62. [CrossRef]

42. Sheane, R.; Lewis, K.; Hall, P.; Holmes-Ling, P.; Kerr, A.; Stewart, K.; Webb, D. Identifying Opportunities to Reduce the Carbon Footprint Associated with the Scottish Dairy Supply Chain-Main Report; Scottish Government: Edinburgh, UK, 2011.

43. Shi, C.W.P.; Rugrungruang, F.; Yeo, Z.; Song, B. Carbon footprint analysis for energy improvement in flour milling production. In Glocalized Solutions for Sustainability in Manufacturing; Springer: Berlin/Heidelberg, Germany, 2011; pp. 246-251.

(C) 2020 by the authors. Licensee MDPI, Basel, Switzerland. This article is an open access article distributed under the terms and conditions of the Creative Commons Attribution (CC BY) license (http://creativecommons.org/licenses/by/4.0/). 